\title{
PENINGKATAN KETERAMPILAN BERBICARA DENGAN PENDEKATAN KOMUNIKATIF-INTEGRATIF DI SMK NUSANTARA PLUS TANGERANG SELATAN
}

\author{
Rerin Maulinda \\ Universitas Pamulang \\ dosen00445@unpam.ac.id
}

\begin{abstract}
This study aims to improve students' speaking skills with a communicative-integrative approach at SMP Nusantara Plus Tangerang Selatan with the material of continuing the story. The subjects of this study were students of class 7A who were relevant to 30 people. The design in this research is classroom action research (classroom action research) which is conducted in three cycles. The data aids used are observation, interviews. The results of the study in cycles 1-3 said that the students' ability in speaking through the communicative-integrative approach had a significant increase. This increase can be seen based on the average value obtained when students carry out the teaching and learning process with the material continuing the story. In the first cycle, the number of students who told stories was 30 students with $70.55 \%$. In the second cycle, 37 students who told stories had increased by $73.46 \%$. In the third cycle, the number of students who told stories was 39 students with a percentage of $83.67 \%$ increased by $9.89 \%$. The increase in speaking ability also increases with the increase in the average student activity during learning. The average student activity in cycle I was $65.30 \%$. Student activity in cycle II had an increase of $9.48 \%$, which was $75.77 \%$, and activity in cycle III was $89.90 \%$, which was an increase of $11,65 \%$ of the average activity in cycle II. With the results obtained in each cycle, it is clear that they try to express their ideas and ideas when telling stories using communicative language and pay attention to linguistic and non-linguistic elements.
\end{abstract}

Keywords: Speaking skills, and a communicative-integrative approach

\section{ABSTRAK}

Penelitian ini bertujuan untuk mengetahui peningkatan keterampilan berbicara siswa dengan pendekatan komunikatif-integratif di SMP Nusantara Plus Tangerang Selatan dengan materi melanjutkan cerita. Subyek penelitian ini adalah siswa kelas 7A yang berjumlah 30 orang. Desain dalam penelitian ini adalah penelitian tindakan kelas (classroom action research) yang dilakukan dalam tiga siklus. Adapun alat pengumpulan data yang digunakan adalah observasi, wawancara. Adapun hasil penelitian pada siklus 1-3 dikatakan bahwa kemampuan siswa dalam berbicara melalui pendekatan komunikatif-integratif mengalami peningkatan yang cukup signifikan. Peningkatan ini dapat diketahui berdasarkan nilai rata-rata yang diperoleh ketika siswa melakukan proses kegiatan belajar mengajar dengan materi melanjutkan cerita. Pada siklus I jumlah siswa yang bercerita sebanyak 30 siswa dengan prosentase 70,55\% Pada siklus II jumlah siswa yang bercerita mengalami peningkatan sebesar $3.58 \%$, yaitu sebanyak 37 siswa dengan persentase $73,46 \%$. Pada siklus III jumlah siswa yang bercerita mengalami peningkatan sebesar 9,89\%, yaitu sebanyak 39 siswa dengan prosentase $83,67 \%$. Peningkatan kemampuan berbicara juga diikuti dengan peningkatan rata-rata aktivitas siswa selama pembelajaran. Rata-rata aktivitas siswa pada siklus I sebanyak 65,30\%, aktivitas siswa pada siklus II mengalami peningkatan sebesar 9,48\%, yaitu sebanyak $75,77 \%$, dan aktivitas pada siklus III sebanyak $89,90 \%$, yaitu mengalami peningkatan sebesar $11,65 \%$ dari rata-rata aktivitas pada siklus II. Dengan hasil yang didapatkan pada setiap siklus, terlihat jelas bahwasanya Mereka berusaha mengemukakan ide dan gagasannya ketika bercerita dengan menggunakan bahasa yang komunikatif dan memperhatikan unsur-unsur kebahasaan dan nonkebahasaan.

Kata Kunci : Keterampilan Berbicara, dan pendekatan komunikatif-integratif

Peningkatan Keterampilan Berbicara dengan Pendekatan Omunikatif-Integratif di SMK

Nusantara Plus Tangerang Selatan 


\section{A. PENDAHULUAN}

Berbicara adalah kemampuan untuk mengatakan suara artikulasi atau kata-kata untuk mengekspresikan, mengekspresikan, atau mengirimkan pikiran, gagasan, dan perasaan. Dalam hal ini keterampilan berbicara telah dimiliki oleh setiap orang yang sangat membutuhkan dalam komunikasi, baik untuk satu cara dalam karakter maupun timbal balik atau keduanya.

Manusia dalam kehidupan sehari-hari senantiasa dihadapkan pada kegiatan berbicara. Di manapun kita berada, kita selalu dituntut kemampuan berbicara. Dengan berbicara seseorang berusaha mengungkapkan pikiran dan perasaannya kepada orang lain secara lisan. Mengingat begitu produktifnya kegiatan berbicara, Soenardi (1996: 68) menegaskan bahwa keterampilan berbicara merupakan bagian dari kemampuan berbahasa yang bersifat aktif-produktif.

Secara umum dikatakan bahwa dalam pembelajaran di sekolah saat ini, masih banyak siswa yang masih kurang terampil berbicara. Banyak dari siswa-siswi menghadapi beragam kendala dalam mengungkapkan sesuatu hal di hadapan teman-temannya, ataupun sekadar bercerita di depan kelas atau pun berdiskusi secara teratur. Terkadang persoalan ini membuat mereka enggan apalgi bergabung dalam pembelajaran yg berkaitan dengan bicara

Hal ini menimbulkan hal tak baik dalam setiap pembelajaran. selain kurang rasa percaya diri, maka terbuangnya waktu percuma hanya untuk menanti keberanian siswa-siswi. Dengan adanya keterampilan berbicara diharapkan para siswa dapat dapat berkomunikasi dengan semua orang, sehingga mampu memberikan pendapat dan mempresentasikan hasi diskusi melalui bahasa lisan

Seorang guru yang baik selalu berpikir untuk mengaktifkan siswanya dalam belajar. Siswa perlu diberi kesempatan untuk mengalami, mencoba, dan melaksanakan atau mempraktikan apa yang dipelajarinya untuk memperoleh hasil yang lebih mantap. Hal seperti ini diamanatkan pula dalam Kurikulum 2006, yaitu pusat dalam proses belajar mengajar adalah siswa sebagai pembelajar, sedangkan guru hanya dijadikan sebagai motivator. Hal ini juga dikemukakan oleh Tarigan (1986: 88), keadaan pengajaran berbicara, sejalan dengan keadaan pengajaran bahasa Indonesia, belum memuaskan. Keterampilan berbicara dalam arti luas, para pelajar belum memadai. Kenyataan dalam diskusi, seminar, ataupun ceramah menunjukkan bahwa sebagian besar pesertanya diam, kurang bersuara.

Kecakapan beradu argumentasi masih jauh dari memadai. Faktor-faktor penyebabnya yaitu siswa jarang berlatih, kurang adanya kesinambungan antara keterampilan berbahasa yang satu dengan ketiga keterampilan berbahasa lainnya, dan guru masih kurang memberikan motivasi kepada siswa serta mungkin pula guru kurang terampil dalam mengajarkan keterampilan berbicara. Hal inilah yang mendorong untuk memberikan tindakan khusus dalam pembelajaran melalui pendekatan komunikatif-integratif yang menyatupadukan seluruh keterampilan berbahasa, tetapi dalam penelitian ini penulis memfokuskan pada satu keterampilan, yaitu keterampilan berbicara. Tujuan diadakan penelitian ini adalah untuk memperoleh gambaran hasil belajar siswa dalam pembelajaran keterampilan berbicara melalui pendekatan komunikatif-integratif.

\section{B. TINJAUAN PUSTAKA}

Guntur Tarigan

(1981:

mengemukakan bahwa keterampilan berbicara adalah kemampuan mengucapkan bunyi-bunyi artikulasi atau kata-kata untuk mengekspresikan, mengatakan serta menyampaikan pikiran, gagasan, dan perasaan. Pendengar menerima informasi melalui rangkaian nada, tekanan dan penempatan persendian, jika komunikasi berlangsung, secara tatap muka ditambah lagi dengan gerak tangan dan air muka (mimik pembicara). Djago Tarigan (1990: 149) menyatakan bahwa berbicara adalah keterampilan menyampaikan pesan melalui bahasa lisan. Kaitan antara pesan dan bahasa lisan sebagai media penyampaian sangat erat. Pesan yang diterima oleh pendengar tidaklah dalam wujud asli, tetapi dalam bentuk lain yaitu 
bunyi bahasa. Pendengar kemudian mencoba mengalihkan pesan dalam bentuk bunyi bahasa itu menjadi bentuk semula.

Arsjad Mukti U.S (1993: 23) mengemukakan pula bahwa kemampuan berbicara adalah kemampuan mengucapkan kalimatkalimat untuk mengekspresikan, menyatakan, menyampaikan pikiran, gagasan, dan perasaan. Tujuan umum berbicara menurut Djago Tarigan (1990: 149) terdapat lima golongan berikut ini: 1) berbicara untuk menghibur 2) berbicara untuk tujuan menginformasikan 3) berbicara untuk menstimulasi pendengar 4) berbicara untuk menggerakkan pendengarnya.

Sedangkan jenis-jenis berbicara menurut Guntur Tarigan (1981: 22-23) memasukkan beberapa kegiatan berbicara ke dalam kategori: 1) berbicara di muka umum, meliputi: (a) berbicara yang bersifat memberitahukan (informative speaking) (b) berbicara dalam situasi membujuk (persuasive speaking) (c) berbicara yang bersifat merundingkan (deliberate speaking) 2) diskusi kelompok 3) prosedur parlementer 4) debat. Dari pembagian jenis berbicara itu, jelas bahwa berbicara mempunyai ruang lingkup pendengar yang berbeda-beda. Faktor-faktor yang mempengaruhi efektivitas berbicara,

Arsjad dan Mukti U.S. (1993: 17- 20) mengemukakan bahwa untuk menjadi pembicara harus menguasai masalah yang sedang dibicarakan dan harus berbicara dengan jelas dan tepat. Beberapa faktor yang harus diperhatikan oleh pembicara untuk keefektifan berbicara adalah faktor kebahasaan dan nonkebahasaan. Faktor kebahasaan yang menunjang kefektifan berbicara, ketepatan ucapan, penempatan tekanan, nada sandi, dan durasi yang sesuai, pilihan kata, dan ketepatan sasaran. Faktor-faktor nonkebahasaan meliputi: sikap yang wajar, tenang dan tidak kaku, pandangan harus diarahkan pada lawan berbicara, kesediaan menghargai pendapat orang lain, gerak-gerik dan mimik yang tepat, kenyaringan suara, kelancaran, relevansi atau penalaran, dan penguasaan topik.

Rusmiati (2002: 30) mengemukakan bahwa terdapat sejumlah ciri-ciri pembicara yang baik untuk dikenal, dipahami, dan dihayati, serta dapat diterapkan dalam berbicara. Ciricirinya meliputi: 1) memilih topik yang tepat, 2) menguasai materi, 3) memahami latar belakang pendengar, 4) mengetahui situasi, 5) tujuan jelas, 6) kontak dengan pendengar 7) kemampuan linguistiknya tinggi, 8) menguasai pendengar, 9) memanfaatkan alat bantu, 10) penampilannya meyakinkan, 11) berencana.

Rusmiati (2002: 32) mengemukakan bahwa hambatan yang datangnya dari pembicara sendiri (internal) dan hambatan yang datang dari luar pembicara (eksternal). Kegiatan berbicara juga merupakan kegiatan yang membutuhkan berbagai macam pengetahuan yang sangat kompleks, salah satunya adalah sikap mental. Sikap mental yang harus dibina oleh seorang pembicara pada saat berbicara, yaitu: 1) rasa komunikasi, 2) rasa percaya diri, 3) rasa kepemimpinan. Aminudin (1983: 12) mengemukakan bahwa rasa kepemimpinan yang berhubungan dengan kegiatan berbicara adalah rasa percaya diri dari pembicara bahwa dirinya mampu mengatur, menguasai, dan menjalin suasana akrab dengan pendengarnya, serta mampu menyampaikan idenya dengan baik.

Berikut ini terdapat beberapa hal mengenai kriteria penilaian menurut Suhendar (1992: 118-131) bahwa menilai kemampuan berbicara seseorang sekurangkurangnya ada enam hal yang diperhatikan, seperti: lafal, struktur, kosakata, kefasihan, isi pembicara, dan pemahaman. Sedangkan Sapani (1990: 12-16) berpendapat mengenai penilaian keterampilan berbicara keterampilan berbicara ini mencakup tiga aspek sebagai berikut: (1) bahasa lisan yang digunakan, meliputi: lafal dan intonasi, pilihan kata, struktur bahasa, serta gaya bahasa dan pragmatik; (2) isi pembicara, meliputi: hubungan isi topik, struktur isi, kuantitas isi, serta kualitas isi; (3) teknik dan penampilan, meliputi: gerak-gerik dan hubungan dengan pendengar, volume suara, serta jalannya pembicara. Kegiatan pengajaran bahasa yang hanya berpusat pada guru sebagai sumber pengetahuan akan berdampak negatif terhadap perkembangan siswa.

Bila mengkaji kurikulum 2006 dan silabus bidang bahasa Indonesia, terdapat 
pendekatan khusus bidang studi Sekolah Menengah Pertama (SMP), yaitu pendekatan komunikatif, integratif, dan pendekatan tematis.

Bahan pelajaran utama untuk pendekatan komunikatif, pendekatan integratif ini adalah keempat keterampilan berbahasa. Pengembangan kompetensi pendekatan komunIkatif dan integratif melibatkan aspek kognitif dan tingkah laku yang diperoleh melalui praktik Pendekatan komunikatif mewakili studi bahasa yang memberikan kemampuan bahasa keterampilan untuk didukung oleh pengetahuan bahasa.

Pendekatan komunikatif diajarkan untuk memperoleh informasi yang diperlukan dalam kehidupan sehari-hari agar siswa memahami penelitian yang lebih memiliki makna. Pendekatan komunikatif ini dapat memberikan kebebasan kepada siswa untuk mengutarakan pendapat secara lisan dan juga merangkai katakata untuk diberitahukan kepada temantemannya dengan sendirinya. Prinsip dasar pendekatan komunikatif adalah: a) item harus terdiri dari bahasa sebagai sarana komunikasi, b) item desain harus menekankan proses belajar mengajar non diskusi fundamental, c) item harus mendukung siswa untuk berkomunikasi dengan cara biasanya.

Strategi belajar mengajar dalam pendekatan komunikatif bergantung pada cara pembelajaran siswa aktif, yaitu siswa terlibat dalam proses belajar secara aktif. Strategi berdasarkan prosedur pendekatan komunikatif yaitu memendekkan presentasi dialog, mempresentasikan dialog pelatihan lisan, presentasi pertanyaan dan jawaban, observasi dan studi, penarikan kesimpulan, aktivitas interaktif, pembuatan tugas dan evaluasi pelaksanaan.

Oleh karena itu, melalui pendekatan komunikasi siswa diharapkan dapat mengatur keterampilan berbicara sehingga mampu meningkatkan keterampilan berbicara yang dievaluasi sesuai, keakuratan, dan kefasihan berbicara. Melalui pembelajaran pendekatan komunikatif juga dapat mengevaluasi kekurangan siswa secara intensif dan memberikan bimbingan yang diperlukan agar aktivitas belajar lebih aktif dengan minat dan interaktif

Berdasarkan hal di atas peneliti berpendapat bahwa dalam pengajaran keterampilan berbahasa melalui pendekatan komunikatif-integratif inilah yang tepat, sebab mengacu pada pengembangan dan penyajian materi pelajaran bahasa secara terpadu. Istilah pendekatan integratif adalah memadukan keterampilan berbahasa yakni membaca, menulis, menyimak, dan berbicara dalam suatu kesatuan yang utuh, hal ini didukung oleh pendapat dari Tarigan (1990: 81) yang mengatakan bahwa pengajaran bahasa dengan pendekatan komunikatif berpusat pada siswa, interaksi lisan dianggap sama pentingnya dengan membaca dan menulis.

\section{METODE PENELITIAN}

Metode yang digunakan dalam penelitian ini yaitu tindakan kelas (classroom action research) yang berupaya untuk mengkaji dan merefleksi suatu pendekatan pembelajaran dengan tujuan meningkatkan proses dan produk pengajaran. Proses pembelajaran tidak terlepas dari adanya interaksi antara guru dengan siswa, siswa dengan guru, siswa dengan siswa, materi, dan sumber belajar yang digunakan, sehingga fokus dalam penelitian ini mengarah pada hasil dan proses belajar siswa. Mengenai kegiatan belajar mengajar di kelas, akan disesuaikan dengan materi pembelajaran. Kegiatan setiap siklusnya terdiri atas perumusan kembali permasalahan yang dihadapi kemudian memformulasikan alternatif pemecahan, perencanaan dan persiapan tindakan, pelaksanaan tindakan, dan observasi pembelajaran, serta evaluasi kegiatan dan refleksi. Subjek penelitian ini adalah siswa kelas VIIIB SMP Nusantara Plus Tangerang Selatan yang berjumlah 30 siswa.

Dalam melaksanakan penelitian, penulis dibantu oleh observer. Sedangkan instrumen yang digunakan untuk menjaring data penelitian ini berupa angket, observasi, dan catatan lapangan. Angket yaitu cara pengumpulan data melalui sejumlah pernyataan yang disampaikan kepada responden (siswa) secara tertulis. Tujuan angket ini adalah untuk mengetahui sejauh mana

Peningkatan Keterampilan Berbicara dengan Pendekatan Omunikatif-Integratif di SMK 50 Nusantara Plus Tangerang Selatan 
respon dan perkembangan siswa terhadap penerapan pendekatan komunikatif-integratif yang difokuskan untuk meningkatkan keterampilan berbicara.

Observasi pada penelitian tindakan kelas dipusatkan pada proses maupun hasil tindakan pembelajaran beserta segala peristiwa yang melingkupinya. Observasi ini dilakukan untuk memperoleh data mengenai aktivitas siswa dan aktivitas guru selama proses pembelajaran berlangsung. Hal-hal yang diamati terhadap aktivitas guru selama proses pembelajaran sebagai berikut: (1) kemampuan membuka pelajaran; (2) sikap guru dalam proses pembelajaran; (3) proses pembelajaran; (3) proses pembelajaran; (4) kemampuan menggunakan media (tema cerita yang menarik); dan (5) kemampuan menutup pelajaran.

Hal-hal yang harus diamati terhadap aktivitas siswa dalam proses pembelajaran yaitu: (1) keaktifan siswa berbicara, khususnya dalam bercerita; (2) aktivitas siswa dalam mengemukakan idenya ketika bercerita; (3) keseriusan siswa dalam mengikuti proses belajar mengajar, dan (4) keseriusan siswa dalam mengerjakan tugas yang diberikan guru. Catatan lapangan yang digunakan dalam penelitian ini adalah untuk mengungkapkan temuantemuan selama pembelajaran berupa aktivitas siswa dalam berkomunikasi, melanjutkan cerita, dan menulis apa-apa yang telah diceritakan.

Prosedur penelitian dengan tahapan: (1) identifikasi masalah; (2) perencanaan dan persiapan tindakan; (3) pelaksanaan tindakan; (4) pemantauan selama proses penelitian tindakan kelas dilaksanakan mulai siklus I, siklus II, sampai siklus III; (5) analisis dan refleksi; (6) pelaksanaan tindakan tercapai.

Data dalam penelitian ini diperoleh melalui kegiatan pembelajaran keterampilan berbicara, yaitu dengan cara mengamati setiap aktivitas yang dilakukan selama penelitian berlangsung. Pengolahan data untuk mengungkapkan tingkat relevansi kegiatan guru dalam pembelajaran diolah secara kualitatif melalui penskoran dalam skala ordinal. Tingkat keberhasilan akan dibagikan menjadi empat kategori yaitu kurang, cukup, baik, dan baik sekali dengan klasifikasi sebagai berikut.

Tabel 1. Penilaian Kategori

\begin{tabular}{|c|c|}
\hline 4 & Sangat baik \\
\hline 3 & Baik \\
\hline 2 & Cukup \\
\hline 1 & Kurang \\
\hline
\end{tabular}

Pengolahan data untuk mengukur keefektifan siswa selama pembelajaran diolah secara kualitatif dikonversi dalam bentuk penskoran kuantitatif.

Data untuk mengukur aktivitas siswa selama pembelajaran diolah setelah pengumpulan data yang dilakukan melalui pedoman observasi aktivitas siswa. Penskoran kuantitatif dibagi menjadi lima kategori skala ordinal, yaitu sangat baik, baik, cukup, dan kurang, dengan klasifikasi sebagai berikut:

Tabel 2 Rentang Skor Kuantitatif

\begin{tabular}{|c|c|}
\hline$>80 \%$ & Sangat baik \\
\hline $70 \%-79,99 \%$ & Baik \\
\hline $69,00 \%-60 \%$ & Cukup \\
\hline $59 \%-0 \%$ & Kurang \\
\hline
\end{tabular}

Pengolah data untuk aspek kognitif siswa diolah secara kuantitatif langsung melalui penskoran dalam skala ordinal.

Tingkat keberhasilan akan dikelompokkan menjadi lima kategori skala ordinal, yaitu sangat tinggi, tinggi, sedang, dan rendah, dengan tabel sebagai berikut:

Tabel 3 Rentang Skor Aspek Kognitif

\begin{tabular}{|c|c|}
\hline$>80 \%$ & Sangat tinggi \\
\hline $70 \%-79,99 \%$ & tinggi \\
\hline $69,00 \%-60 \%$ & Sedang \\
\hline $59 \%-0 \%$ & Rendah \\
\hline
\end{tabular}

Pengolahan data untuk aspek afektif siswa diolah secara kuantitatif, kemudian dikonversi ke dalam bentuk pen skoran kuantitatif penskoran kuantitatif dikelompokkan menjadi empat kategori skala ordinal, yaitu sangat baik, baik, cukup, dan kurang, dengan tabel sebagai berikut.

Tabel 4. Rentang Skor Aspek Afektif Siswa

\begin{tabular}{|c|c|}
\hline$>80 \%$ & Sangat baik \\
\hline $70 \%-79,99 \%$ & Baik \\
\hline $69,00 \%-60 \%$ & Cukup \\
\hline $59 \%-0 \%$ & Kurang \\
\hline
\end{tabular}




\section{HASIL PENELITIAN}

Hasil temuan di lapangan mengenai pembelajaran keterampilan berbicara pada siswa kelas VIII SMP Nusantara Plus Tangerang Selatan melalui pendekatan komunikatif. Peneliti berperan sebagai perencana, pelaksana, dan pengajar di kelas selama penelitian tindakan kelas berlangsung.Penelitian dilaksanakan selama dua siklus, tiap siklus terdiri dari dua kali pertemuan.Alokasi waktu tiap pertemuan adalah 70 menit ( 2 x 35 menit).

Berdasarkan metodologi penelitian yang disebutkan di atas, penulis menyajikan hasil analisis data secara bertahap yang meliputi tiga siklus sebagai berikut.

4.1 Data pada Siklus 1

Berdasarkan pengamatan terhadap aktivitas guru selama pembelajaran berlangsung, secara keseluruhan guru telah melaksanakan hampir semua tahapan. Guru sebagai model masih merasa kesulitan mengatur waktu dan menggali ide siswa untuk berbicara, terutama ketika meminta siswa untuk memulai cerita baru dan meminta siswa untuk melanjutkan cerita siswa yang lain. Sementara itu, aspek memberikan kesempatan kepada siswa untuk mengajukan pertanyaan, tidak ada siswa yang mengajukan pertanyaan mengenai kesulitannya.

Secara umum aktivitas siswa selama menerapkan pembelajaran keterampilan berbicara melalui pendekatan komunikatifintegratif tergolong cukup dengan prosentase rata-rata pencapaian $45,87 \%$. Hal ini diakibatkan karena sebagian siswa masih terlihat kesulitan mendapatkan ide dan malu bercerita. Penekanan pada kegiatan pembelajaran mempengaruhi terhadap aktivitas siswa.

Berdasarkan hasil observasi keseriusan dan keantusiasan selama proses pembelajaran berlangsung, sudah menunjukkan baik kategori baik. Hal ini disebabkan karena jumlah 30 siswa di kelas 7A, terdapat 19 siswa yang berani cerita. Jadi, lebih dari setengah siswa yang sudah ikut berpartisipasi dalam proses belajar mengajar. Berdasarkan deskripsi hasil pembelajaran keterampilan berbicara dengan materi melanjutkan cerita, diperoleh 70,55\% siswa yang bercerita. Bagi penulis, hal ini merupakan bahan refleksi yang akan dijadikan dasar dalam penyusunan tindakan pembelajaran siklus II.

Secara lengkap diuraikan sebagai berikut. 1) Kemampuan siswa menggunakan inntonasi dengan tepat ketika bercerita ketika bercerita masih tergolong rendah yaitu $70,55 \%$. Hal ini karena siswa yang intonasinya kurang tepat masih banyak 35,49\% dan yang tidak tepat sejumlah 2,5\%. 2) Kejelasan cerita siswa yang dapat dimengerti dan dipahami oleh siswa lain tergolong kategori rendah dengan prosentase $30,06 \%$. Hal ini disebabkan oleh kejelasan cerita siswa masih banyak yang kurang dipahami siswa lainnya dengan prosentase $30,61 \%$ dan cerita siswa yang tidak dimengerti sama sekali oleh siswa yang lain sebanyak 2,04\%. 3) Kemampuan siswa mengaitkan antara cerita siswa yang satu dengan cerita siswa yang lain tergolong dalam kategori tinggi dengan prosentase $65,30 \%$. Akan tetapi masih terdapat siswa yang kurang mengaitkan antara cerita yang satu dengan cerita siswa yang lain, yaitu dengan prosentase $14,30 \%$. Kemampuan siswa lancar pada saat jalannya berbicara, khususnya dalam pnguasaan isi cerita tergolong rendah dengan prosentase $20,40 \%$.

Hal ini disebabkan masih kurang lancarnya ketika bercerita yaitu dengan prosentase $40 \%$ dan siswa yang tidak lancar bercerita $14,91 \%$. Kemampuan siswa dalam menggunakan kata/ kalimat yang tepat ketika bercerita tergolong dalam kategori rendah dengan prosentase $30,48 \%$. Hal ini disebabkan oleh banyaknya siswa yang masih kurang tepat menggunakan kalimat/kata ketika bercerita dengan prosentase $14,24 \%$.

\subsection{Data pada Siklus 2}

Berdasarkan data yang diperoleh di atas, penulis sebagai peneliti merasa perlu untuk melakukan perbaikan-perbaikan dalam pembelajaran siklus II, sehingga diperoleh hasil yang lebih baik. Pada siklus II diperoleh hasil sebagai berikut. Berdasarkan hasil observasi terhadap aktivitas guru, secara keseluruhan guru telah melaksanakan rencana pembelajaran dengan kategori baik. Hal yang harus

Peningkatan Keterampilan Berbicara dengan Pendekatan Omunikatif-Integratif di SMK 52 Nusantara Plus Tangerang Selatan 
ditingkatkan pada siklus II ini adalah pengalokasian waktu.

Rata-rata aspek aktivitas siswa pada pembelajaran siklus II mencapai $63,77 \%$ dengan kategori baik, tetapi perlu ditingkatkan aspek kebahasaan dan respon siswa terhadap pertanyaan guru. Aspek afektif siswa, terutama aspek keseriusan dan keantusiasan siswa selama proses pembelajaran berlangsung diperoleh $77,77 \%$ siswa yang melanjutkan cerita berada dalam kategori baik selain itu respon siswa ketika guru mulai cerita dengan judul Tersengat Lebah semua siswa merespon dengan sangat baik dengan prosentase $100 \%$

Berdasarkan deskripsi hasil pembelajaran keterampilan berbicara dengan materi melanjutkan cerita, berada dalam kategori baik, secara lengkap diuraikan: 1) Kemampuan siswa menggunakan intonasi dengan tepat ketika bercerita tergolong cukup, yaitu dengan prosentase $55,10 \%$. Hal ini diakibatkan masih terdapat siswa yang intonasinya kurang tepat yaitu dengan prosentase $14,28 \%$ dan yang tidak tepat $13,28 \%$., 2) Kejelasan siswa cerita yang dapat dimengerti dan dipahami oleh siswa lain tergolong dalam kategori cukup dengan prosentase $50 \%$. 3) Kemampuan siswa mengaitkan antara cerita siswa yang satu dengan yang lain tergolong tinggi yaitu $73,46 \%$. 4) Kemampuan siswa lancar pada saat jalannya berbicara, khususnya dalam penguasaan isi cerita tergolong cukup dengan prosentase $55,43 \%$ tegolong cukup dengan prosentase $55,43 \%$. 5) Kemampuan siswa dalam menggunakan kata/ kalimat yang tepat ketika bercerita tergolong kategori cukup dengan prosentase $42,60 \%$.

\subsection{Data pada Siklus 3}

Data yang diperoleh pada siklus II masih belum memenuhi target yang diharapkan sesuai dengan tujuan. Maka penulis bersama observer membuat kembali rencana pembelajaran pada siklus III, dengan hasil sebagai berikut. Berdasarkan hasil observasi terhadap aktivitas guru, secara keseluruhan guru telah melaksanakan rencana pembelajaran dengan menunjukkan kategori baik. Rata-rata aspek aktivitas siswa pada pembelajaran siklus III ini mencapai $82 \%$. Aspek afektif siswa, terutama aspek keseriusan dan keantusiasan siswa selama proses pembelajaran berlangsung diperoleh $83,67 \%$, siswa yang melanjutkan cerita, yaitu berada dalam kategori baik. Selain itu respon siswa $100 \%$ yang berada dalam kategori sangat baik.

Berdasarkan deskripsi hasil pembelajaran keterampilan berbicara dengan materi melanjutkan cerita, berada dalam kategori baik, secara lengkap diuraikan sebagai berikut. 1) Kemampuan siswa menggunakan intonasi dengan tepat ketika bercerita tergolong cukup, yaitu dengan prosentase $70.50 \%$. Hal ini diakibatkan masih terdapat siswa yang intonasinya kurang tepat yaitu dengan prosentase $29,50 \%$. 2) Kejelasan siswa cerita yang dapat dimengerti dan dipahami oleh siswa lain tergolong dalam kategori tinggi dengan prosentase $71,42 \%$. 3) Kemampuan siswa mengaitkan antara cerita siswa yang satu dengan yang lain tergolong tinggi yaitu $83,67 \%$. 4) Kemampuan siswa lancar pada saat jalannya berbicara, khususnya dalam penguasaan isi cerita tergolong tinggi dengan prosentase $63,26 \%$.

Berdasarkan hasil penelitian ini, dapat dikatakan bahwa kemampuan siswa dalam berbicara melalui pendekatan komunikatifintegratif mengalami peningkatan yang cukup signifikan. Peningkatan tersebut dapat dilihat dari perolehan skor siswa mulai dari siklus I sampai III. Peningkatan ini dapat diketahui berdasarkan nilai rata-rata yang diperoleh ketika siswa melakukan proses kegiatan belajar mengajar dengan materi melanjutkan cerita. Pada siklus I jumlah siswa yang bercerita sebanyak 30 siswa dengan prosentase $70,55 \%$ Pada siklus II jumlah siswa yang bercerita mengalami peningkatan sebesar $3.58 \%$, yaitu sebanyak 37 siswa dengan persentase $73,46 \%$. Pada siklus III jumlah siswa yang bercerita mengalami peningkatan sebesar $9,89 \%$, yaitu sebanyak 39 siswa dengan prosentase $83,67 \%$.

Peningkatan kemampuan berbicara juga diikuti dengan peningkatan rata-rata aktivitas siswa selama pembelajaran. Rata-rata aktivitas siswa pada siklus I sebanyak $65,30 \%$, aktivitas siswa pada siklus II mengalami peningkatan 
sebesar 9,48\%, yaitu sebanyak $75,77 \%$, dan aktivitas pada siklus III sebanyak 89,90\%, yaitu mengalami peningkatan sebesar $11,65 \%$ dari rata-rata aktivitas pada siklus II.

Aktivitas siswa dalam proses pembelajaran, mulai siklus I sampai siklus III terjadi peningkatan yang cukup berarti. Respon dan motivasi siswa untuk belajar berbicara di depan umum menunjukkan respon positif. Hal ini ditunjukkan dengan keseriusan siswa dalam memperbaiki kesalahan dan kekurangan pada setiap siklus pembelajaran. Mereka berusaha mengemukakan ide dan gagasannya ketika bercerita dengan menggunakan bahasa yang komunikatif dan memperhatikan unsur-unsur kebahasaan dan nonkebahasaan.

\section{E. SIMPULAN DAN SARAN}

Berdasarkan seluruh uraian di atas, diperoleh tiga kesimpulan umum sebagai berikut. Pertama, Siswa lebih termotivasi untuk belajar berbicara dan mengikuti pembelajaran melalui pendekatan komunikatif integratif. Kedua, kemampuan berbicara siswa dalam menggunakan bahasa yang efektif mulai dapat diperbaiki dengan melakukan pengoreksian oleh guru ketika siswa melanjutkan cerita. Ketiga, siswa menjadi lebih berani untuk berbicara di depan umum, khususnya di depan teman-teman kelasnya.

Berdasarkan temuan-temuan dan kesimpulan penelitian ini, peneliti merasa perlu untuk memberikan tiga saran sebagai berikut. Pertama, proses pembelajaran keterampilan berbicara dapat membangkitkan motivasi siswa jika didukung dengan memberikan variasi pembelajaran dengan menghadirkan materi yang menarik, misalnya materi melanjutkan cerita dengan judul yang menarik, seperti yang telah dilakukan, sehingga kita sebagai guru harus selalu berusaha untuk mencari alternatif jalan keluar terbaik sehingga proses pembelajaran bisa lebih berhasil dan bermakna. Kedua, proses pembelajaran keterampilan berbicara sesungguhnya dapat dengan mudah diterapkan, karena tidak menimbulkan kejenuhan dan kebosanan siswa Ketiga, pendekatan komunikatif-integratif dapat menyentuh semua keterampilan berbahasa yang lain di dalam pembelajaran.

\section{DAFTAR PUSTAKA}

Arikunto, Suharsimi. 1998. Prosedur Penelitian Suatu Pendekatan Praktek. Yogyakarta: Rieke Cipta. Arsyad, Mukti. 1984.

Arsjad, Maidar G. \& Mukti U.S. 1998. Pembinaan Kemampuan Berbicara bahasa Indonesia. Jakarta: Erlangga.

Asih. 2015. Strategi Pembelajaran Bahasa Indonesia, Bandung:Pustaka Setia.

Azie Furqanul \& Chaedar Alwasilah. 2002. Pengajaran Bahasa Komunikatif. Bandung: Rosda

Hopkins, David. 2011. Panduan Guru Penelitian Tindakan Kelas (A Teacher's Guide Classroom Research).Yogyakarta: Pustaka Belajar.

Madya, Suwarsih. 2011. Penelitian Tindakan Action Research . Bandung: Alfabeta.

Nurgiyantoro, Burhan. 2014. Penilaian Pembelajaran Bahasa. Yogyakarta: BpFE.

Pembinaan Kemampuan Berbicara Bahasa Indonesia. Jakarta: Erlangga. Departemen Pendidikan Nasional. 2001.

Kamus Besar Bahasa Indonesia. Edisi Ketiga. Jakarta: Balai Pustaka. _.2003.

Penelitian Tindakan Kelas. Jakarta: Direktorat Tenaga Kependidikan. Rakhmat, Jalaludin. 2001.

Retorika Moderen Pendekatan Praktis. Bandung: PT Remaja Rosdakarya.

Rusmiati, Nepi. 2002. Model Show Case dalam Pembelajaran Keterampilan Berbicara. Bandung: Alfa.

Surakhmad, Winarno. 1998. Pengantar Penelitian Ilmiah Dasar Metode Teknik. Bandung: Tarsito.

Tarigan, Henry Guntur. 1981. Berbicara Sebagai Suatu Keterampilan Berbahasa. Bandung: Angkasa. - 1986.

Teknik Pengajaran Keterampilan Berbahasa. Bandung: Angkasa. Tarigan, Djago. 1996.

Wassid, Iskandar \& Dadang Suhendar. 2016. Strategi Pembelajaran Bahasa. Bandung; Rosda.

Wiriatmadja, Rochiati. Metode Penelitian Tindakan Kelas. Bandung;Remaja Rosdakarya. 
Zulela, 2013. Pembelajaran Bahasa Indonesia. Bandung: Rosda. 